\title{
Fertilizer application enhances establishment of cacao seedlings in plant- parasitic nematodes infected soil
}

\author{
Samuel Bukola ORISAJO ${ }^{1,2}$ and Kayode Babatunde ADEJOBI ${ }^{1}$
}

Received April 26, 2019; accepted April 29, 2020.

Delo je prispelo 26. aprila 2019, sprejeto 29. aprila 2020.

Fertilizer application enhances establishment of cacao seedlings in plant-parasitic nematodes infected soil

Abstract: Low soil fertility, pests and diseases are major problems of growth and establishment of cacao seedlings on the field. Cocoa production increases by new plantings and rehabilitation of moribund farms, but a build-up of plantparasitic nematodes (PPN) causing dieback and declining soil fertility has discouraged many farmers, leading to a reduction in crop productivity. In this study, the potentials of some organic wastes as fertilizers and their effects on establishment of cacao seedlings in PPN infected soils was investigated at Ibadan and Owena of Southwestern Nigeria. Goat dung (GD), organic fertilizer (OF), organo-mineral fertilizers (OMF) and NPK 15:15:15 were applied at 200, 400 and $600 \mathrm{~kg}$ ha-1, respectively, to cacao seedlings one month after transplanting, while unfertilized served as control. Results from the experiments showed a significant increase in percentage survival of cacao seedlings under organic fertilizers at Ibadan and Owena compared to NPK and control even at the lowest rate of $200 \mathrm{~kg} \mathrm{ha}^{-1} 3$ years after transplanting. The incorporation of GD, OF and OMF significantly reduced the population densities of PPN compared to control. Therefore, GD, OF and OMF at $200 \mathrm{~kg} \mathrm{ha}^{-1}$ are recommended for soil application to enhance the field establishment of cacao seedlings in the soil infected with PPN.

Key words: fertilizers; plant-parasitic nematodes; cacao seedlings; establishment; organic wastes
Uporaba gnojil pospešuje rast sadik kakavovca v tleh okuženih s parazitskimi ogorčicami

Izvleček: Slaba rodovitnost tal, škodljivci in bolezni so glavni problem pri vzgoji sadik kakavovca na prostem. Pridelava kakava se povečuje $\mathrm{z}$ novimi nasadi in obnovo zanemarjenih kmetijskih zemljišč, a pojav parazitskih ogorčič (PPN), ki povzročajo propad sadik in zmanjšana rodovitnost tal jemljeta pri tem mnogim kmetom pogum, kar vodi $\mathrm{v}$ zmanjšanje $\mathrm{v}$ pridelavi te kulture. $\mathrm{V}$ tej raziskavi je bil preučevan potencial nekaterih organskih ostankov kot gnojil in njihov vpliv na rast sadik kakavovca v z ogorčicami (PPN) okuženih tleh v Ibadanu in Oweni, v jugovzhodni Nigeriji. Uporabljeni so bili kozji gnoj (GD), organska gnojila (OF), organsko-mineralna gnojila (OMF) in NPK $15: 15: 15$ v odmerkih 200, 400 in $600 \mathrm{~kg}$ ha ${ }^{1}$, v nasadu kakavovca en mesec po presaditvi in kot kontrola nepognojen nasad. Rezultati poskusa so pokazali značilno povečanje preživetja sadik kakavovca pri gnojenju z organskimi gnojili v Ibadanu in Oweni v primerjavi z gnojenjem s NPK in kontrolo, celo pri najmanjšem gnojenju z organskimi gnojili, $200 \mathrm{~kg} \mathrm{ha}^{-1}$, 3 leta po presaditvi. Vnašanje GD, OF in OMF v tla je značilno zmanjšalo gostoto populacij ogorčic $\mathrm{v}$ primerjavi $\mathrm{s}$ kontrolo. Zaradi tega priporočamo gnojenje z GD, OF in OMF v odmerku $200 \mathrm{~kg} \mathrm{ha}^{-1}$ za uspešno rast sadik kakavovca v tleh okuženih s parazitskimi ogorčicami.

Ključne besede: gnojila; rastlinske parazitske ogorčice; sadike kakavovca; uspešna vzgoja; organski odpadki

1 Cocoa Research Institute of Nigeria, Crop Protection, Agronomy and Soil Division, Ibadan, Nigeria

2 Corresponding author, e-mail: sambukki@yahoo.com 


\section{INTRODUCTION}

Cocoa (Theobroma cacao L.) is cultivated in the humid tropics of the world (Yanelis et al., 2012) with more than $70 \%$ production coming from Africa as a source of income for producing countries (Simo et al., 2018). The crop production is dominated by small-scale farmers who live and work in the cocoa belt providing them employment and income (Minimol et al., 2015; Ngoh Dooh et al., 2015). However, cocoa production has witnessed a downward trend due to declining soil fertility, pests and diseases, aging trees and low yields from smallholder farms. Low farm gate prices paid to farmers make it difficult for them to afford expensive inputs to increase soil fertility and yield, such as mineral fertilizers, and pesticides to control pests and diseases adverse effects. There are also concerns that the projected global temperature rise and subsequent increase in potential evapotranspiration and demand for plant water may lead to further drought stress during the dry season and deterioration of cocoa climate conditions (Läderach et al., 2013; Schroth et al., 2016). Cocoa production increases through new plantings and rehabilitation of moribund farms, but the build-up of plant-parasitic nematodes causing die-back of cacao seedlings in nurseries and young plantations and declining soil fertility caused many farmers to be discouraged leading to a reduction in crop productivity (Orisajo et al., 2012; Orisajo, 2018). The need to pay attention to soil fertilization is now almost as important as the control of pests and diseases in cocoa. Tropical soils are inherently low in soil organic matter and fertility status; hence external fertilizer supply is a key factor in raising crop production.

Fertilization is an indispensable agricultural practice in which organic and inorganic fertilizers are used primarily to improve plant nutrition and hence crop productivity (Tian et al., 2015; Francioli et al., 2016). Inorganic fertilizers which perform a decisive role in improving crop productivity are wildly applied. The production and application of these fertilizers cause serious environmental damage like greenhouse gas emissions, eutrophication (Copetti et al., 2016), pollution (De Notaris et al., 2018), leaching and contamination of groundwater thereby posing risk to human health (Huang et al., 2018; Jalali \& Latifi, 2018). The continuous application of NPK leads to increase in the soil compactness, decrease in the soil $\mathrm{pH}$ (Adamtey et al., 2016), soil porosity, and organic carbon level (Chaudhary et al., 2017) as well as decrease in soil beneficial microorganism populations (Wei et al., 2017). Continuous excessive applications of inorganic fertilizer can also lead to nutrient accumulation in soil, and eventual $\mathrm{P}$ and $\mathrm{N}$ loss from soil to aquatic ecosystems (Qiao et al., 2012; Yan et al., 2013). Excessive $\mathrm{N}$ and $\mathrm{P}$ applications will also deteriorate the soil quality and reduce the soil's production levels (Zhang et al., 2015). With rising costs of chemical fertilizer and the aforementioned growing concerns over the environmental impact of excessive fertilizer application, there has been an increasing scrutiny on how nutrients are managed on farms (Chen et al., 2014).

Organic fertilizers (manures) are gaining attention as the alternative to inorganic fertilizers. Organic manure produced from biomass and animal conventionally plays an important role in recycling of nutrients (Hasler et al., 2015). When added to soils, organic manure enhances soil fertility by increasing nutrient availability (Cavagnaro, 2014), soil organic carbons (Xie et al., 2014), available $\mathrm{N}$ and $\mathrm{P}$, micronutrients, soil aggregation, and water holding capacity, as well as leading to a high soil buffering capacity against external disturbances (Yu et al., 2012; Liang et al., 2012; Chaudhary et al., 2012; Sogn et al., 2018). Though, the benefits associated with organic amendments majorly depend upon the type and application rate of organic fertilizers (Jones \& Healey, 2010).

The application of organic material, though a traditional practice to improve soil fertility and structure, is also known as a control method for soil- borne diseases, including plant-parasitic nematodes (Hassan et al., 2010; Houx et al., 2014). In recent years, a variety of organic materials, such as animal and green manures, compost, and proteinaceous wastes, are used for this purpose (Summers, 2011; Stirling et al., 2011; Renco \& Kovacik, 2012; Olabiyi \& Oladeji, 2014; Abolusoro et al., 2015; Rudolph \& DeVetter, 2015; Tiyagi et al., 2015; Briar et al., 2016; Forge et al., 2016; Atandi et al., 2017; Shiferaw et al., 2017). Incorporation of organic amendments has been shown to be detrimental to plant parasitic nematodes (Wang et al., 2004) due to release of $\mathrm{NH}_{4}$, formaldehyde, phenol, volatile fatty acids and toxic compounds (Oka, 2010; McSorley, 2011; Briar et al., 2016). It was generally postulated that the adverse influence of organic amendment on plant-parasitic nematode is referred to increasing host resistance to nematode infection and enhancement of growth performance (Country \& Millon, 2008).

This work aims to examine the effects of organic and organo-mineral fertilizers on plant-parasitic nematodes, cacao seedlings growth and establishment on the field. This will possibly ameliorate the current frustration faced by small-scale farmers on poor establishment of cacao seedlings and thereby increasing the crop production and income.

\section{MATERIALS AND METHODS}

\subsection{STUDY AREA}

Field experiments were carried out at the Cocoa Re- 
search Institute of Nigeria (CRIN) experimental farms in Ibadan, Oyo State and Owena, a CRIN Substation in Ondo State, Nigeria. Ibadan lies between the latitude $7^{0}$ $30^{\prime} \mathrm{N}$ and longitude $3^{\circ} 54^{\prime} \mathrm{E}$ at an altitude of $1222 \mathrm{~m}$ above sea level. It is located in the tropical rain forest ecosystem with mean solar radiation of $18 \mathrm{MJ} \mathrm{m}^{-2}$ day $^{-1}$ and an annual average rainfall of $2000 \mathrm{~mm}$ with a bimodal pattern. Owena lies between the latitude $7^{0} 15^{\prime} \mathrm{N}$ and longitude $5^{0}$ $12^{\prime} \mathrm{E}$ at an altitude of $367 \mathrm{~m}$ above sea level. It is located in the tropical rain forest ecosystem with mean solar radiation of $30 \mathrm{MJ} \mathrm{m}^{-2}$ day $^{-1}$ and an annual average rainfall of $1500 \mathrm{~mm}$ with a bimodal pattern.

The experiment was conducted over three years on the False horn plantain (Musa spp. L., AAB - group 'Agbagba') as shade crop planted with cacao (Theobroma cacao 'F3 Amazon') in Ibadan and Owena. The experiment was set as a randomized complete block design involving four fertilizer types: goat dung (GD), organic (OF), organo-mineral fertilizer (OMF) and NPK 15:15:15, which were separately applied at 200,400,600kg ha-1 and unfertilized served as control. Each treatment had 3 replications. Healthy sword suckers of plantain of approximately uniform size (50-60 cm tall, 30-40 cm pseudostem girth) pared to remove lesions were planted at a spacing of $3 \mathrm{x}$ $3 \mathrm{~m}$. Cocoa seedlings of 5 months old were planted four weeks later at the same spacing.

\subsection{PROCUREMENT OF FERTILIZERS AND PROXIMATE ANALYSIS}

Organic (OF) and organo-minerals fertilizers (OMF) used for the experiments were obtained from the Sunshine Fertilizers, Ministry of Agriculture, Ondo State. They were manufactured in 2016 with batch numbers 30172, 30110, respectively. Goat dung (GD) was collected from Goat farms in Ilesha Garage, Akure, Ondo State. The GD was collected from pens with good farm sanitation, air-dried, carefully sorted to remove foreign materials and packed in $50 \mathrm{~kg}$ bags. The analysis was conducted to determine the nutrient content of the fertilizers using the wet digestion method (Odu et al., 1986). After drying, the fertilizer sample was finely ground in a mortar at approximately $80{ }^{\circ} \mathrm{C}$ for 12 hours. The $0.5 \mathrm{~g}$ sample was then weighed into a $100-\mathrm{ml}$ Berzelius beaker. Five millilitres $(5 \mathrm{ml})$ of nitric acid $\left(\mathrm{HNO}_{3}\right)$ and $2 \mathrm{ml}$ of perchloric acid $\left(\mathrm{HClO}_{4}\right)$ were added, covered with a watch glass and digested by heating to a final volume of $5 \mathrm{ml}$. Ten millilitres $(10 \mathrm{ml})$ of water was then added and the digested solution was filtered through an acid-washed filter paper into a $50 \mathrm{ml}$ volumetric flask. The filter paper was washed with water and the filtrate diluted to volume with deionized water. The filtrate was read under atomic adsorp- tion spectrometer, flame photometer and colorimeter for macro and micronutrients in the sample.

\subsection{SOIL SAMPLES COLLECTION AND ANALYSIS}

Soil samples were collected randomly from each of the experimental sites at both locations (Ibadan and Owena) with the aid of soil auger at $0-30 \mathrm{~cm}$ depth. For the pre-cropping analysis, the samples were bulked together and mixed thoroughly, air dried at room temperature and analysed for various elements. Particle analysis was determined using the hydrometer method (Kettler et al., 2001). Organic carbon determination was by the potassium dichromate oxidation method (Zhang et al., 2001). The total nitrogen (N) was determined by Kjeldahl method; available P by ammonium-vanadomolybdate colorimetric method; exchangeable $\mathrm{K}$ and $\mathrm{Na}$ by flame photometer; and exchangeable $\mathrm{Mg}$, $\mathrm{Ca}$ and $\mathrm{Mn}$ were determined using atomic absorption spectrophotometer (Ryan et al., 2001). Soil pH was read on pH meter (1:1 water). Soil was assayed to confirm the presence and the initial population density of the plant-parasitic nematodes (Coyne et al., 2007). Aliquots of $100 \mathrm{ml}$ soil was put into a set up that has two plastic sieves with extractor tissue sandwiched in between. The plastic sieves with the soil were thereafter placed in a plastic bowl, and water was added to the extraction bowl just enough to wet the soil. The set-up was left undisturbed for 48 hours. Thereafter, the plastic sieve containing the soil was removed briskly, and the nematode suspension in the bowl was poured into a nalgene wash bottle and allowed to settle. The supernatant was siphoned out, and the suspension containing nematodes was then poured into a labelled beaker, and adjusted to $10 \mathrm{ml}$ by adding water. This was homogenized and $1 \mathrm{ml}$ of the suspension was taken with the use of pipette, dispensed into the nematode counting dish and examined under a high power stereomicroscope. Nematodes were transferred with a picker to a slide with a drop of water, covered (with a cover slip) and examined under an Olympus compound microscope for identification using taxonomic keys (UNL, 2019) and counted. The identification and counting was repeated three times and mean population of nematodes per sample calculated. Two grams (2 g) each of the organic fertilizers used were also analysed for nutrient composition.

\subsection{FERTILIZER APPLICATION AND DATA COL- LECTION}

The fertilizers were applied to treatment plots one month after transplanting using ring method of appli- 
cation at $5 \mathrm{~cm}$ away from the base of cacao. Monthly Data collection on growth parameters (plant height, stem girth, number of leaf, and leaf area and number of branches) commenced 3 months after transplanting. Leaf samples ( $4^{\text {th }}$ leaf $)$ were collected from 4 tagged cocoa seedlings at 12 months after transplanting and were analysed in the laboratory for chemical composition. The experiments were monitored for 36 months (144 weeks after planting). Survival count was carried out 12 months after transplanting. At 15 months after transplanting, soil samples were collected from treatment plots and were processed and analysed for physical properties (sand silt, loam, clay, soil moisture content and soil bulk density), chemical properties (soil organic matter, soil $\mathrm{pH}, \mathrm{N}$, $\mathrm{P}, \mathrm{K}, \mathrm{Mg}$, Ca, and $\mathrm{Na}$ ), and plant-parasitic nematodes population densities using aforementioned standard procedures.

\subsection{DATA ANALYSIS}

Nematode population densities were $\log _{10}(\mathrm{x}+1)$ transformed and percentage data were square-root-transformed prior to analysis to stabilize variances (Gomez \& Gomez, 1984), while the other data collected were not transformed. Only the predominant plant-parasitic nematode species were included in the data analysis. Analyses of variance (ANOVA) were carried out to test for main effects and interactions. Pre-planned comparisons between treatment combinations were tested with linear contrasts. All analyses were performed using GENSTAT.

\section{RESULTS AND DISCUSSIONS}

\subsection{NUTRIENT COMPOSITION OF THE ORGANIC MATERIALS}

The nutrient composition of the organic materials ap- plied to the soil is presented in Table 1 . The $\mathrm{C}: \mathrm{N}$ ratio of the organic fertilizers used are 8.2, 9.4, 9.8 for goat dung, organo-mineral fertilizer and organic fertilizer, respectively. Changes in the $\mathrm{C}: \mathrm{N}$ ratio of aggregates may reflect the degree of organic materials decomposition within aggregate fractions (Baldock et al., 1992). Higher C : N ratios of aggregates suggest that soil organic $\mathrm{C}$ is relatively fresh or little altered, whereas, soil organic $\mathrm{C}$ is more decomposed and relative aged when the $\mathrm{C}: \mathrm{N}$ ratio of aggregates is low (Chen et al., 2010). Difference in soil organic matter quality within aggregate fractions will result in difference in the types of nutritional substrates available, which may directly affect the natural microbial communities (Bending et al., 2002). In general, amending the soil with organic materials having low $\mathrm{C}: \mathrm{N}$ ratio (less than 20 ) resulted in rapid mineralization of $\mathrm{N}$ in the form of $\mathrm{NH}_{4+}$ or $\mathrm{NO}_{3}-$ for absorption and uptake by plant roots (Powers \& McSorley, 2000). The fertilizers used in these experiments have low $\mathrm{C}: \mathrm{N}$ and this appeared to have positive effects on the survival of the cacao seedlings.

\subsection{SURVIVAL AND GROWTH OF CACAO SEED- LINGS AS AFFECTED BY FERTILIZER APPLICA- TION}

Results indicated that fertilizers applied significantly $(p<0.05)$ increased the survival of cocoa seedlings 12 months after planting in the field. The percentage survival of cacao seedlings under organic fertilizers at Ibadan and Owena increased significantly compared to NPK and control even at the lowest rate of $200 \mathrm{~kg} \mathrm{ha}^{-1}$ used in the experiment (Table 2). However, application of 600 and $400 \mathrm{~kg} \mathrm{ha}^{-1}$ of NPK enhanced the survival of the cacao seedlings compared to the control. In the same vein, growth of cacao seedlings was consistently improved by the fertilizer application compared with the control at both locations (Table 3). Application of goat dung, organo-mineral fertilizer and organic

Table 1: The nutrient composition of the organic materials

\begin{tabular}{llll}
\hline Properties & Goat dung $(\mathrm{GD})$ & Organo-mineral fertilizer (OMF) & Organic fertilizer (OF) \\
\hline $\mathrm{pH}($ water) & $8.17 \pm 0.04$ & $7.00 \pm 0.03$ & $7.30 \pm 0.02$ \\
Organic carbon (\%) & $40.1 \pm 0.13$ & $40.5 \pm 0.12$ & $36.4 \pm 0.13$ \\
Organic matter (\%) & $69.1 \pm 0.15$ & $69.8 \pm 0.14$ & $62.8 \pm 0.15$ \\
Total nitrogen (\%) & $4.9 \pm 0.01$ & $4.3 \pm 0.01$ & $3.7 \pm 0.01$ \\
Available P $(\mathrm{cmol} \mathrm{kg})$ & $113.24 \pm 0.17$ & $138.06 \pm 0.17$ & $7.08 \pm 0.17$ \\
$\left.\mathrm{~K}^{+}(\mathrm{cmol} \mathrm{kg})^{-1}\right)$ & $0.41 \pm 0.01$ & $0.19 \pm 0.01$ & $5.56 \pm 0.01$ \\
$\mathrm{Mg}^{++}\left(\mathrm{cmol} \mathrm{kg}^{-1}\right)$ & $1.20 \pm 0.01$ & $1.00 \pm 0.01$ & $6.00 \pm 0.01$ \\
$\mathrm{Ca}^{++}(\mathrm{cmol} \mathrm{kg})$ & $2.60 \pm 0.12$ & $2.00 \pm 0.12$ & $13.10 \pm 0.15$ \\
$\mathrm{Na}^{+}(\mathrm{cmol} \mathrm{kg}$ & $0.1)$ & $0.18 \pm 0.01$ & $2.30 \pm 0.02$ \\
$\mathrm{C}: \mathrm{N}$ & $8.2 \pm 0.03$ & $9.4 \pm 0.04$ & $9.8 \pm 0.03$ \\
\hline
\end{tabular}


fertilizer at 200, 400 and $600 \mathrm{~kg} \mathrm{ha}^{-1}$ led to a significant increase in the height of cacao compared with NPK and control (Table 3). Similar pattern was observed for other growth parameters measured. In contrast, there was a significant reduction in plant height, stem girth, number of leaves, leaf area and number of branches of cacao in unfertilized plots. The increase in growth parameters could be attributed to the enhanced nitrogen and phosphorus uptake by the plant using organic amendments (Pandit et al., 2018). Organic manures have been shown to supply required plant nutrients, improve soil structure and promote plant growth (Agbede et al., 2014, 2017). The addition of organic manure in soil may encourage the immobilization of bioavailable nitrogen and phosphorus, which may otherwise be lost through leaching or emissions in the environment (Sun et al., 2018). The inclusion of organic manure may also generate higher transpiration rates leading to higher water retention in the soil. Hence, more availability of water soluble nutrients may cause the crop yield improvement (Doan et al., 2015).

Application of inorganic fertilizer, NPK, even at the lowest rate $200 \mathrm{~kg}$ ha-1 also improved cacao growth significantly compared with the control (Table 3 ). This is in agreement with the earlier study that the use of appropriate levels of NPK fertilizers have good effects on plant growth factors (Irshad et al., 2006). NPK application enriched the availability of macro nutrients, nitrogen, phosphate, and potassium in the soil. These nutrients therefore, were readily absorbed by the crops. In crop metabolism, these nutrients are utilized in carbohydrate synthesis, cellulose, proteins, hormones, and enzymes. All these processes triggered the growth of plant organs such as plant height, stem diameter, number of leaves, leaf area and number of branches as reported in this present study. This result was in line with the previous studies conducted by Mandal et al. (2009) and Bandyopadhyay et al. (2010). In their studies, applications of NPK also triggered the growth of vegetative crops.

\subsection{RELATIONSHIPS BETWEEN PLANT-PARASITIC NEMATODES AND CACAO GROWTH}

Relationships between the predominant plant-parasitic nematode population densities recovered and vegetative growth of young cacao revealed various statistically significant interactions (Table 4). Meloidogyne incognita (Kofoid \& White, 1919) Chitwood, 1949, Pratylenchus coffeae Goodey, 1951 and Radopholus similis (Cobb, 1893) Thorne, 1949 population densities were negatively correlated with the survival percentage of the cacao seedlings $(\mathrm{r}=-0.69, \mathrm{p}<0.01 ; \mathrm{r}=-0.58, \mathrm{p}<0.05$ and $\mathrm{r}=-0.46, \mathrm{p}<$ 0.05 , respectively). Furthermore, $M$. incognita was negatively correlated with the plant height $(\mathrm{r}=0.91, \mathrm{p}<0.01)$, leaf area $(\mathrm{r}=-0.61, \mathrm{p}<0.01)$ and number of branches $(\mathrm{r}=$ $-0.51, \mathrm{p}<0.05)$. This confirmed the previous reports that root-knot nematodes, $M$. incognita, damage on cacao seedlings led to stunted growth of the plants (Afolami \& Caveness, 1983; Afolami \& Ojo, 1984) Similarly, Helicotylenchus multicinctus (Cobb, 1893) Golden, 1956, P. coffeae and $R$. similis population densities were negatively correlated with plant height $(\mathrm{r}=-0.46, \mathrm{p}<0.05 ; \mathrm{r}=-0.51$, $\mathrm{p}<0.05 ; \mathrm{r}=-0.43, \mathrm{p}<0.05$, respectively), while they have no significant correlation with leaf area and number of

Table 2: Survival rate (\%) of cacao seedlings as affected by fertilizer application at Ibadan and Owena (12 months after transplanting)

\begin{tabular}{llll}
\hline & Treatments & Ibadan experiments & Owena experiments \\
\hline Fertilizers & Rates $\left(\mathrm{kg} \mathrm{ha}^{-1}\right)$ & & $94.44 \mathrm{ab}$ \\
\hline Goat dung & 600 & $94.44 \mathrm{a}$ & $94.44 \mathrm{ab}$ \\
& 400 & $94.44 \mathrm{a}$ & $88.33 \mathrm{abc}$ \\
\hline Organo-mineral fertilizer & 600 & $94.44 \mathrm{a}$ & $83.33 \mathrm{abc}$ \\
& 400 & $90.44 \mathrm{a}$ & $83.33 \mathrm{abc}$ \\
\hline Organic fertilizer & 600 & $88.88 \mathrm{a}$ & $83.33 \mathrm{abc}$ \\
\hline & 400 & $77.77 \mathrm{ab}$ & $100.00 \mathrm{a}$ \\
& 200 & $94.44 \mathrm{a}$ & $83.33 \mathrm{abc}$ \\
\hline NPK 15: $15: 15$ & 600 & $90.44 \mathrm{a}$ & $83.33 \mathrm{abc}$ \\
\hline Control & 400 & $83.33 \mathrm{ab}$ & $72.22 \mathrm{bc}$ \\
\hline
\end{tabular}

Treatment means within each column followed by the same letters are not significantly different from each other using Tukey's HSD at $5 \%$ level. 


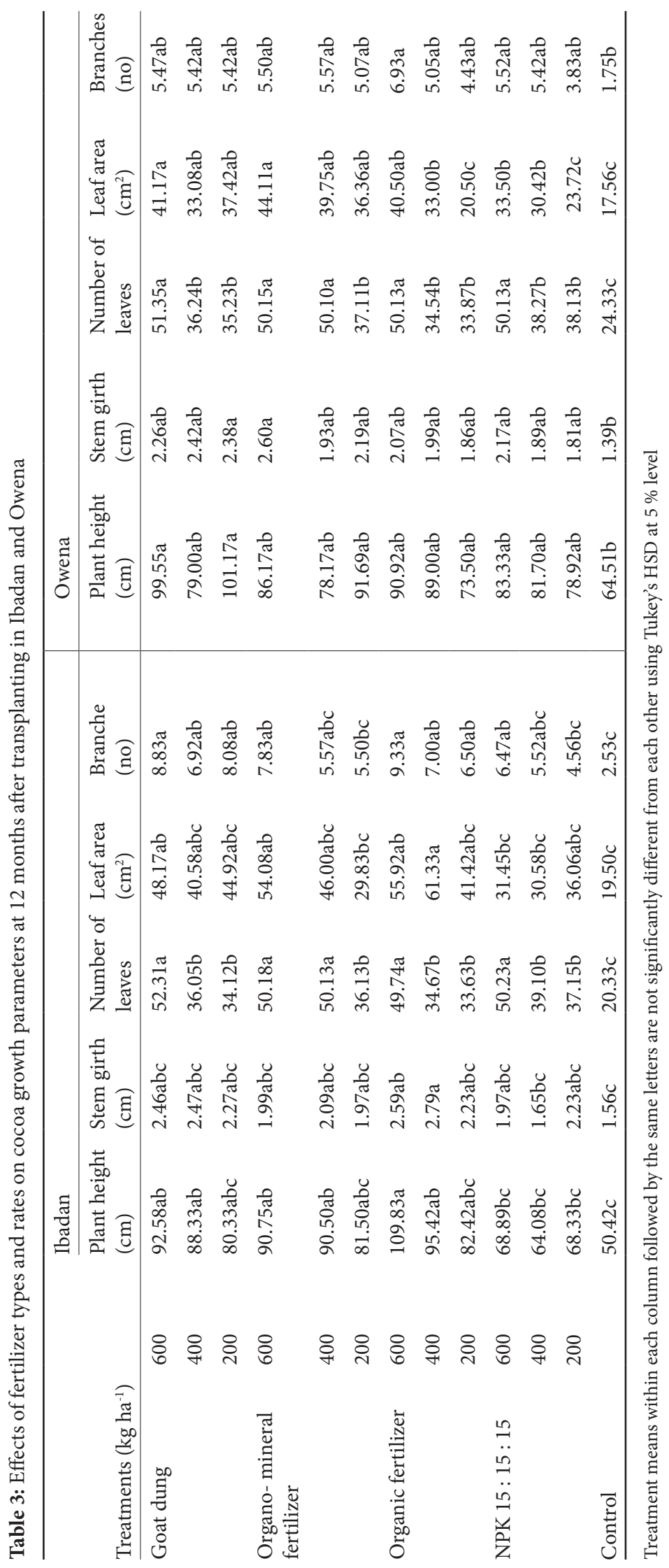


Table 4: Linear correlation matrix (half) of mean values for plant-parasitic nematode population densities / $100 \mathrm{~g}$ soil, percentage survival, plant height, leaf area and branches of young cacao

\begin{tabular}{|c|c|c|c|c|c|c|c|}
\hline & $\mathrm{Hm}$ & $\mathrm{Pc}$ & Rs & $\begin{array}{l}\text { Survival } \\
(\%)\end{array}$ & $\begin{array}{l}\text { Plant height } \\
(\mathrm{cm})\end{array}$ & $\begin{array}{l}\text { Leaf area } \\
\left(\mathrm{cm}^{2}\right)\end{array}$ & $\begin{array}{l}\text { Branches } \\
\text { (no) }\end{array}$ \\
\hline M. incognita (J2) & $0.96^{* *}$ & $0.41^{*}$ & $0.67^{* *}$ & $-0.69^{* *}$ & $-0.91^{* *}$ & $-0.61^{* *}$ & $-0.51^{*}$ \\
\hline H. multicinctus & - & $0.46^{*}$ & $0.72^{* *}$ & 0.24 & $-0.46^{*}$ & -0.12 & -0.24 \\
\hline P. coffeae & & - & $0.84^{* *}$ & $-0.58^{*}$ & $-0.51^{*}$ & -0.15 & -0.18 \\
\hline R. similis & & & - & $-0.46^{*}$ & $-0.43^{*}$ & -0.15 & -0.17 \\
\hline Survival (\%) & & & & - & $0.89^{* *}$ & $0.63^{* *}$ & $0.51^{*}$ \\
\hline Plant height $(\mathrm{cm})$ & & & & & - & $0.71^{* *}$ & $0.53^{*}$ \\
\hline Leaf area $\left(\mathrm{cm}^{2}\right)$ & & & & & & - & 0.28 \\
\hline
\end{tabular}

Mi: Meloidogyne incognita; Hm: Helicotylenchus multicinctus; Pc: Pratylenchus coffeae; Rs: Radopholus similis.

Correlation coefficient significant at ${ }^{*} p<0.05,{ }^{* *} p<0.01$.

branches (Table 4). However, plant height was positively correlated with survival percentage $(\mathrm{r}=0.89, \mathrm{p}<0.01)$, leaf area $(\mathrm{r}=0.71, \mathrm{p}<0.01)$ and number of branches $(\mathrm{r}=$ $0.53, \mathrm{p}<0.05)$.

\subsection{EFFECTS OF ORGANIC FERTILIZERS ON POPULATION DENSITIES OF PLANT-PARA- SITIC NEMATODES}

The incorporation of goat dung, organo-mineral fertilizer and organic fertilizer at 200, 400 and $600 \mathrm{~kg} \mathrm{ha}^{-1}$ led to a significant reduction in the population densities of these plant-parasitic nematodes compared with NPK fertilizer and control (Table 5). This is in agreement with earlier studies that soil amendments with different types of organic manures are effective in reducing the population densities of many soil-borne plant pathogens including plant-parasitic nematodes (Hassan et al., 2010; Shiferaw et al., 2017). Organic manure has been reported to be rich in several compounds especially nitrogen and phenolics (Hassan et al., 2010; Renco \& Kovacik, 2012). Nitrogen in the organic manure after conversion into ammonia (Thoden et al., 2011) has been reported to kill several plant parasitic nematodes (Lazarovits et al., 2001). Phenols and other nematostatic chemicals released from organic matters into amended soil significantly decreased the nematodes population (Oka 2010; Briar et al., 2016). Several researchers using organic soil amendments have reported satisfactory results on the plant growth and yield in a variety of crops with marked reduction in the population of plant-parasitic nematodes (Orisajo et al., 2008; Pakeerathan et al., 2009; Iqbal et al., 2012; Chaudhary \& Kaul, 2013; Abolusoro et al., 2015; Adepoju et al., 2017). All the treated plants showed significant and satisfactory results when compared to untreated control. Our findings in this study are similar with the aforementioned earlier reports. In the same vein, application of NPK at 200, 400 and $600 \mathrm{~kg} \mathrm{ha}^{-1} 600$ also had a significant lower population densities of $M$. incognita, $H$. multicinctus, $P$. coffeae and $R$. similis. Our findings were consistent with earlier studies that the use of appropriate levels of NPK fertilizers have good effects on plant growth factors with resultant reductions in plant-parasitic nematode populations (Irshad et al., 2006; Ameen et al., 2013; Osman et al., 2015; Kolawole et al., 2018). Contrarily, nematode populations were reported to have increased due to NPK and manure combined with chemical fertilizer ( $\mathrm{Hu}$ et al., 2018). Other studies also reported an increase in the total number of nematodes due to the use of chemical fertilizers (Li et al., 2016; Hu et al., 2017).

\section{CONCLUSION}

Improving the agronomic conditions for plant growth is an important factor for increasing the plant tolerance to plant-parasitic nematodes (Charegani et al., 2010). Results from this study have shown that the addition of fertilizers to the soil will improve the survival and growth of cacao seedlings. With rising costs of chemical fertilizer and the growing concerns over the environmental impact of excessive fertilizer application, goat dung, organo-mineral fertilizer and organic fertilizer at $200 \mathrm{~kg} \mathrm{ha}^{-1}$ are recommended for soil application. These have been shown to enhance the field establishment of cacao seedlings in the soil infected with plant-parasitic nematodes.

\section{REFERENCES}

Abolusoro, S.A., Abe, M.O., Abolusoro, P.F. \& Izuogu, N.B. (2015). Control of nematode disease of eggplant (Solanum 


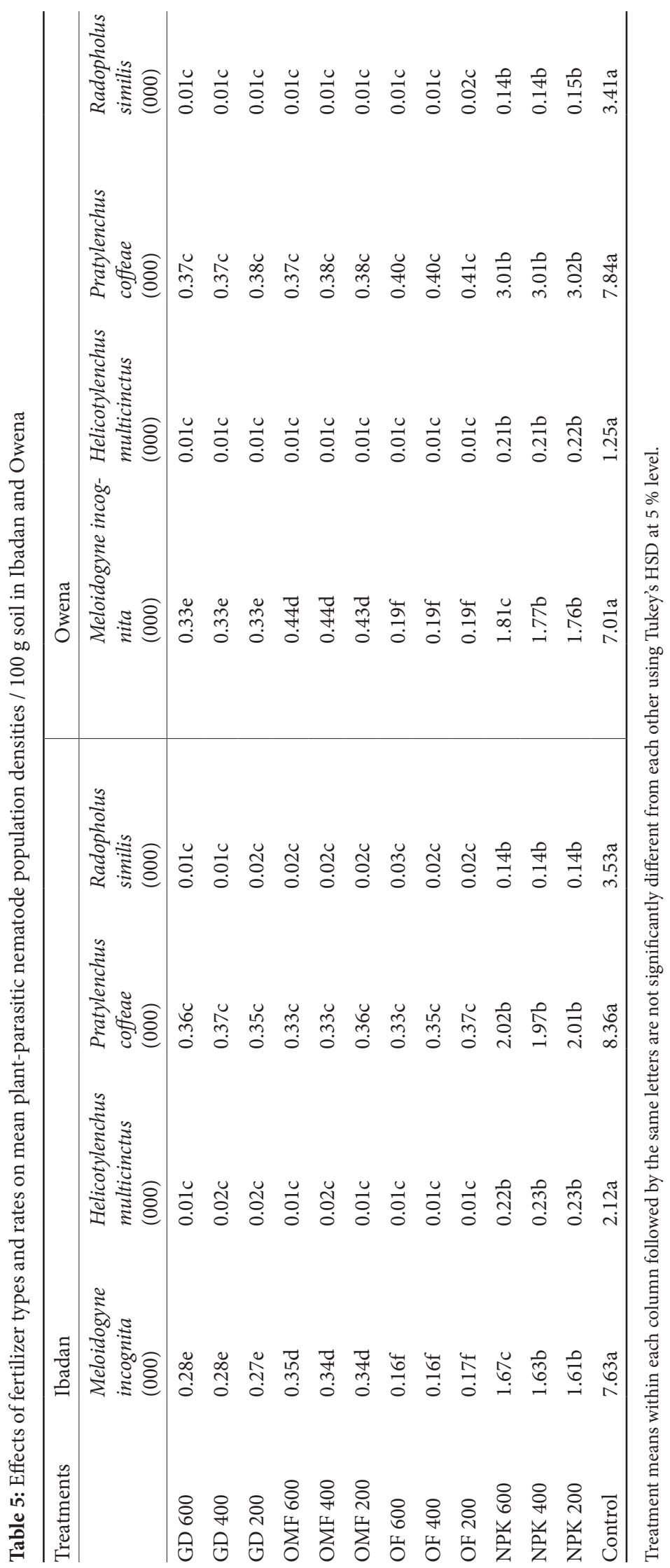


aethiopicum) using manure. Archives of Phytopathology and Plant Protection, 48(2), 188-193. https://doi.org/10.10 80/03235408.2014.882541

Adamtey, N., Musyoka, M.W., Zundel, C., Cobo, J.G., Karanja, E., Fiaboe, K.K.M., Muriuki, A., Mucheru-Muna, M., Vanlauwe, B., Berset, E., Messmer, M.M., Gattinger, A., Bhullar, G.S., Cadisch, G., Fliessbach, A., Mäder, P., Niggli, P. \& Foster, D. (2016). Productivity, profitability and partial nutrient balance in maize-based conventional and organic farming systems in Kenya. Agriculture, Ecosystems and Environment, 235, 61-79. https://doi.org/10.1016/j. agee.2016.10.001

Adepoju, I.O., Olabiyi, T.I., Akanbi, W.B. \& Adeyeye, A.S. (2017). Effect of organic and organomineral fertilizers on growth and yield of okra in nematode infested soil of Ogbomoso North Local Government, Oyo State, Nigeria. Economic Engineering in Agriculture and Rural Development, 17(3), 11-16.

Afolami, S.O. \& Caveness, F.E. (1983). The Frequency of occurrence and geographical distribution of plant parasitic nematodes associated with Theobroma cacao in Nigeria. Turrialba, 33(1), 97-100.

Afolami, S.O \& Ojo, A. A. (1984). Screening of Theobroma cacao germplasm for resistance against a root- knot nematode - Meloidogyne incognita in Nigeria. In: Proceedings, 9th International Cocoa Research Conference (pp. 237-242), Lome, Togo.

Agbede T.M., Adekiya A.O. \& Ogeh J.S. (2014). Response of soil properties and yam yield to Chromolaena odorata (Asteraceae) and Tithonia diversifolia (Asteraceae) mulches. Archives of Agronomy and Soil Science, 60(2), 209-224. https://doi.org/10.1080/03650340.2013.780127

Agbede, T.M., Adekiya, A.O. \& Eifediyi, E.K. (2017). Impact of poultry manure and NPK fertilizer on soil physical properties and growth and yield of carrot. Journal of Horticultural Research, 25(1), 81-88. https://doi.org/10.1515/johr-20170009

Ameen, H. H., Osman, H. A., Lashein, A. M. S., Hasabo, S. A. \& Koura, F. H. (2013). Control of root knot nematode Meloidogyne arenaria on potato in Egypt with plant defense elicitors, bio-agents and inorganic fertilizers. International Journal of Nematology, 23(2), 167-174.

Atandi, J.G., Haukelan, S., Kariuki, G.M., Coyne, D.L, Karanja, E.N., Musyoka, M.W., Fiaboe, K.K.M., Bautze, D. \& Adamtey, N. (2017). Organic farming provides improved management of plant parasitic nematodes in maize and bean cropping systems, Agriculture, Ecosystems and Environment, 247, 265-272. https://doi.org/10.1016/j. agee.2017.07.002

Baldock, JA, Oades, J.M., Waters, A.G., Peng, X., Vassallo, A.M. \& Wilson, M.A. (1992). Aspects of the chemical structure of soil organic materials as revealed by solid-state CNMR spectroscopy. Biogeochemistry, 16, 1-42. https://doi. org/10.1007/BF02402261

Bandyopadhyay, K. K., Misra, A. K., Ghosh, P. K. \& Hati, K. M. (2010). Effect of integrated use of farmyard manure and chemical fertilizers on soil physical properties and productivity of soybean. Soil and Tillage Research, 110(1), 115125. https://doi.org/10.1016/j.still.2010.07.007
Bending, G.D., Turner, M.K. \& Jones, J.E. (2002). Interactions between crop residue and soil organic matter quality and the functional diversity of soil microbial communities. Soil Biology and Biochemistry, 34, 1073-1082. https://doi. org/10.1016/S0038-0717(02)00040-8

Briar, S.S., Wichman, D. \& Reddy, G.V. (2016). Plant-parasitic nematode problems in organic agriculture. In: D. Nandawani (Eds.), Organic Farming for Sustainable Agriculture (pp. 107-122). The Netherlands: Springer International Publishing. https://doi.org/10.1007/978-3-31926803-3_5

Charegani, H.A., Karegar Bideh, A. \& Hamzeh Zarghani, H.A. (2010). Effect of chemical fertilizers on root-knot nematode (Meloidogyne incognita) in greenhouse cucumber cultivation. Iranian Journal of Plant Pathology, 46, 263-274.

Chaudhary, K. K. \& Kaul, R. K. (2013). Efficacy of Pasteuria penetrans and various oil seed cakes in management of Meloidogyne incognita in chilli pepper (Capsicum annum L.). Journal of Agricultural Science and Technology, 15, 617626.

Chaudhary, S., Dheri, G. S. \& Brar, B. S. (2017). Long-term effects of NPK fertilizers and organic manures on carbon stabilization and management index under rice-wheat cropping system. Soil and Tillage Research, 166, 59-66. https:// doi.org/10.1016/j.still.2016.10.005

Chaudhary, V., Rehman, A., Mishra, A., Chauhan, P.S. \& Nautiyal, C.S. (2012). Changes in bacterial community structure of agricultural land due to long-term organic and chemical amendments. Microbial Ecology, 64, 450-460. https://doi. org/10.1007/s00248-012-0025-y

Cavagnaro, T.R. (2014). Impacts of compost application on the formation and functioning of arbuscular mycorrhizas. Soil Biology and Biochemistry, 78, 38-44. https://doi. org/10.1016/j.soilbio.2014.07.007

Chen Y, Zhang, X.D., He, H.B., Xie, H.T., Yan, Y., Zhu, P., Ren, J. \& Wang, L.C. (2010). Carbon and nitrogen pools in different aggregates of a Chinese Mollisol as influenced by longterm fertilization. Journal of Soils Sediments, 10, 10181026. https://doi.org/10.1007/s11368-009-0123-8

Chen, X.P., Cui, Z.L., Fan, M.S., Vitousek, P., Zhao, M., Ma, W.Q., Wang, Z.L., Zhang, W.J., Yan, X.Y., Yang, J.C., Deng, X.P., Gao, Q., Zhang, Q., Guo, S.W., Ren, J., Li, S.Q., Ye, Y.L., Wang, Z.H., Huang, J.L., Tang, Q.Y., Sun, Y.X., Peng, X.L., Zhang, J.W., He, M.R., Zhu, Y.J., Xue, J.Q., Wang, G.L., Wu, L., N., Wu, L.Q., Ma, L., Zhang, W.F. \& Zhang, F.S. (2014). Producing more grain with lower environmental costs. Nature, 514, 486-489. https://doi.org/10.1038/nature13609

Copetti, D., Finsterle, K., Marziali, L., Stefani, F., Tartari, G., Douglas, G., Reitzel, K., Spears, B.M., Winfield, I.J. \& Crosa, G. (2016). Eutrophication management in surface waters using lanthanum modified bentonite: a review. Water Resources, 97, 162-174. https://doi.org/10.1016/j.watres.2015.11.056

Country, R. G. and Millon, G. J. (2008). Soil quality and barley growth as influenced by land application of two compost types. Bioresource Technology, 99, 2913- 2918. https://doi. org/10.1016/j.biortech.2007.06.034

Coyne, D.L., Nicol, J.M. \& Claudius-Cole, B. 2007. Practical plant nematology: a field and laboratory guide. SP-IPM 
Secretariat, International Institute of Tropical Agriculture (IITA), Cotonou, Benin. 84pp.

De Notaris, C., Rasmussen, J., Sørensen, P. \& Olesen, J.E. (2018). Nitrogen leaching: a crop rotation perspective on the effect of $\mathrm{N}$ surplus, field management and use of catch crops. Agriculture Ecosystems and Environment, 255, 1-11. https://doi.org/10.1016/j.agee.2017.12.009

Doan, T.T., Henry-des-Tureaux, T., Rumpel, C., Janeau, J.L. \& Jouquet, P. (2015). Impact of compost, vermicompost and biochar on soil fertility, maize yield and soil erosion in Northern Vietnam: a three year mesocosm experiment. Science of Total Environment, 514, 147-154. https://doi. org/10.1016/j.scitotenv.2015.02.005

Forge, T., Kenney, E., Hashimoto, N., Neilsen, D. \& Zebarth, B. (2016). Compost and poultry manure as preplant soil amendments for red raspberry: comparative effects on root lesion nematodes, soil quality and risk of nitrate leaching agriculture. Ecosystems and Environment, 223, 48-58. https://doi.org/10.1016/j.agee.2016.02.024

Francioli, D., Schulz, E., Lentendu, G., Wubet, T., Buscot, F. \& Reitz, T. (2016). Mineral vs. Organic Amendments: Microbial Community Structure, Activity and Abundance of Agriculturally Relevant Microbes Are Driven by Long-Term Fertilization Strategies. Frontiers in Microbiology, 7(1446), 1-16. https://doi.org/10.3389/fmicb.2016.01446

Gomez, K.A. \& Gomez, A.A. (1984). Statistical procedures for agricultural research. 2nd Edition. New York, USA, John Wiley \& Sons. 653pp.

Hasler, K., Bröring, S., Omta, S. \& Olfs, H.W. (2015). Life cycle assessment (LCA) of different fertilizer product types. European Journal of Agrononomy, 69, 41-51. https://doi. org/10.1016/j.eja.2015.06.001

Hassan, M. A., Chindo, P. S., Marley, P. S. \& Alegbejo, M. D. (2010). Management of root knot nematodes (Meloidogyne spp.) on tomato (Lycopersicon lycopersicum) using organic wastes in Zaria, Nigeria. Plant Protection Sciences, 46, 3438. https://doi.org/10.17221/1/2009-PPS

Houx, I.I.I., Wiebold, W.J. \& Fritschi, F.B. (2014). Rotation and tillage affect soybean grain composition, yield, and nutrient removal. Field Crops Research, 164, 12-21. https://doi. org/10.1016/j.fcr.2014.04.010

Hu, C., Xia, X.G. Han, X. M., Chen, Y. F. Qiao, Y., Liu, D. H. \& Li, S. L. (2018). Soil nematode abundances were increased by an incremental nutrient input in a paddy-upland rotation system. Helminthologia, 55(4), 322 - 333. https://doi. org/10.2478/helm-2018-0025

Hu, J., Chen, G.R., Hassan, W.M., Chen, H., Li, J.Y. \& Du, G.Z. (2017): Fertilization influences the nematode community through changing the plant community in the Tibetan Plateau. European Journal of Soil Biology, 78, 7 - 16. https:// doi.org/10.1016/j.ejsobi.2016.11.001

Huang, P., Zhang, J., Zhu, A., Li, X., Ma, D., Xin, X., Zhang, C., Wu, S., Garland, G. \& Pereira, E.I.P. (2018). Nitrate accumulation and leaching potential reduced by coupled water and nitrogen management in the Huang-Huai-Hai Plain. Science of Total Environment, 610, 1020-1028. https://doi. org/10.1016/j.scitotenv.2017.08.127

Irshad, L., Dawar, S., Zaki, M.J. \& Ghaffar, A (2006). Effect of nursery fertilizers on plant growth and the control of Me- loidogyne javanica root knot nematode on mung bean and okra plants. Pakistan Journal of Botany, 38, 1301-1304.

Iqbal, M. A., Khalid, M., Shahzad, S. M., Ahmad, M., Soleman, N. \& Akhtar, N. (2012). Integrated use of Rhizobium leguminosarum, plant growth promoting rhizobacteria and enriched compost for improving growth, nodulation and yield of lentil (Lens culinaris Medik.). Chilean Journal of Agricultural Research, 72, 104-110. https://doi.org/10.4067/ S0718-58392012000100017

Kolawole, G.O., Haastrup, T.M. and Olabiyi, T.I. (2018). Can arbuscular mycorrhiza fungi and NPK fertilizer suppress nematodes and improve tuber yield of yam (Dioscorea rotundata 'cv' Ewuru)? Eurasian Journal of Soil Science, 7(2), 181 - 186. https://doi.org/10.18393/ejss.384515

Jalali, M. \& Latifi, Z., (2018). Measuring and simulating effect of organic residues on the transport of cadmium, nickel, and zinc in a calcareous soil. Journal of Geochemical Exploration, 184, 372-380. https://doi.org/10.1016/j.gexplo.2017.05.001

Jones, D.L. \& Healey, J.R. (2010). Organic amendments for remediation: putting waste to good use. Elements, 6, 369-374. https://doi.org/10.2113/gselements.6.6.369

Kettler, T.A., Doran, J.W. \& Gilbert, T.L (2001): Simplified method for soil particle-size determination to accompany soilquality. USDA Agricultural Research Service. Lincoln. Nebraka. 852 pp. https://doi.org/10.2136/sssaj2001.653849x

Läderach, P., Martinez, A., Schroth, G. \& Castro, N. (2013). Predicting the future climatic suitability for cocoa farming of the world's leading producer countries, Ghana and Côte d'Ivoire. Climatic Change, 119, 841-854. https://doi. org/10.1007/s10584-013-0774-8

Lazarovits, G., Tenuta, M. \& Conn, K. L. (2001). Organic amendments as a disease control strategy for soilborne diseases of high-value agricultural crops. Australasian Plant Pathology, 30, 111-117. https://doi.org/10.1071/AP01009

Li, N., Pan, F.J., Han, X.Z. \& Zhang, B. (2016). Development of soil food web of microbes and nematodes under different agricultural practices during the early stage of pedogenesis of a Mollisol. Soil Biology and Biochemistry, 98, 208 - 216. https://doi.org/10.1016/j.soilbio.2016.04.011

Liang, Q., Chen, H., Gong, Y., Fan, M., Yang, H. and Lal, R. (2012). Effects of 15 years of manure and inorganic fertilizers on soil organic carbon fractions in a wheat-maize system in the North China Plain. Nutrient Cycling in Agroecosystems, 92, 21-33. https://doi.org/10.1007/s10705-0119469-6

Mandal, K. G., Hati, K. M. \& Misra, A. K. (2009). Biomass yield and energy analysis of soybean production in relation to fertilizer-NPK and organic manure. Biomass and Bioenergy, 33(12), 1670-1679. https://doi.org/10.1016/j.biombioe.2009.08.010

McSorley, R. (2011). Overview of organic amendments for management of plant-parasitic nematodes, with case studies from Florida. Journal of Nematology, 43, 69-81.

Minimol, J.S., Suma, B., Mahiya, U. \& Chithira, P.G. (2015). Genetic improvement of cocoa by developing superior hybrids. Journal of Tropical Agriculture, 53(2), 157-165.

Ngoh Dooh, J.P., Ambang, Z., Ndongo, B., Kuate Tueguem, W.N., Heu, A. \& Ntsomboh Ntsefong, G. (2015). Develop- 
ment of Cocoa Black Pod Disease (Caused by Phytophthora megakarya) in Cameroon when Treated with Extracts of Thevetia peruviana or Ridomil. International Journal of Current Research in Biosciences and Plant Biology, 2(3), 47-59.

Odu, C.T.I., Babalola, O., Udo, E.J., Ogunkunle, A.O., Bakare, T.A. \& Adeoye, G.O. (1986). Laboratory Manual for agronomic Studies in Soil, Plant and Microbiology (83pp). Department of Agronomy, University of Ibadan, Ibadan: UI Press.

Olabiyi, T.I. \& Oladeji, O.O. (2014). Assessment of four compost types on the nematode population dynamics in the soil sown with okra. International Journal of Organic Agricultural Research and Development, 9, 146-155.

Oka, Y.H. (2010). New strategies for the control of plant parasitic nematodes. Pest Management Science, 56, 983-988. https://doi.org/10.1002/1526-4998(200011)56:11<983::AIDPS233>3.0.CO;2-X

Orisajo, S.B. (2018). Nematode Pests of Cocoa. In: P. Umaharan (Eds), Achieving Sustainable Cultivation of Cocoa (pp. 327-343). Cambridge, UK: Burleigh Dodds Science Publishing. https://doi.org/10.19103/AS.2017.0021.20

Orisajo, S. B., Afolami, S. O., Fademi, O.A. \& Atungwu, J. J. (2008). Effects of poultry litter and carbofuran soil amendments on Meloidogyne incognita attacks on cacao. Journal of Applied Biosciences, 7, 214-221.

Orisajo, S.B., Afolami, S.O., Fademi, O.A., Okelana, M.A.O. \& Atungwu, J.J. (2012). Effects of Poultry Litter on Establishment of Cocoa Seedlings and Plantain infected with Parasitic Nematodes. International Journal of Research in Chemistry and Environment, 2(4), 278-289.

Osman, H. A., Ameen, H. H., Mohamed, M. M. \& Alkelany, U. S. (2015). Effect of integrating inorganic fertilizer with either miconema, compost, or oxamyl on suppressing plant parasitic nematode Meloidogyne incognita infecting tomato plants under field conditions. Middle East Journal of Agriculture, 4, 707-711.

Pakeerathan, K., Mikunthan, G. \& Tharshani, N. (2009). Effect of different animal manure on Melodoigyne incognita (Kofoid and White) on tomato. World Journal of Agricultural Sciences, 5, 432-435.

Pandit, N.R., Mulder, J., Hale, S.E., Martinsen, V., Schmidt, H.P. \& Cornelissen, G. (2018). Biochar improves maize growth by alleviation of nutrient stress in a moderately acidic lowinput Nepalese soil. Science of Total Environment, 625, 1380-1389. https://doi.org/10.1016/j.scitotenv.2018.01.022

Powers, L.E. \& McSorley, R. 2000. Ecological principles of agriculture. Delmar Thomson Learning, Albany, NY.

Qiao, J., Yang, L.Z., Yan, T.M., Xue, F. \& Zhao, D. (2012). Nitrogen fertilizer reduction in rice production for two consecutive years in the Taihu Lake area. Agriculture, Ecosystems and Environment, 146, 103-112. https://doi.org/10.1016/j. agee.2011.10.014

Renco, M. \& Kovacik, P. (2012). Response of plant parasitic and free living soil nematodes to composted animal manure soil amendments. Journal of Nematology, 44, 329-336.

Rudolph, R.E. \& DeVetter, L.W. (2015). Management strategies for Phytophthora rubi and Pratylenchus penetrans in flori- cane red raspberry (Rubus idaeus L.). Journal of the American Pomological Society, 69, 118-136.

Ryan, J., Estefan, G. \& Rashid, A. (2001). Soil and plant analysis laboratory manual, 2nd edition. The International Centre for Agricultural Research in the Dry Areas (ICARDA) and the National Agricultural Research Centre (NARC), Aleppo, Syria. 172pp.

Schroth, G., Läderach, P., Martinez-Valle, A.I., Bunn, C. \& Jassogne, L. (2016). Vulnerability to climate change of cocoa in West Africa: Patterns, opportunities and limits to adaptation. Science of the Total Environment, 556, 231-241. https://doi.org/10.1016/j.scitotenv.2016.03.024

Shiferaw, T., Dechassa, N. \& Sakhuja, P. K. (2017). Management of root-knot nematode Meloidogyne incognita (Kofoid and White) Chitwood in Tomato (Lycopersicon esculentum Mill. through poultry manure and rapeseed cake. Journal of Horticulture and Forestry, 9(7), 59-65. https://doi. org/10.5897/JHF2016.0463

Simo, C., Djocgoue, P.F., Minyaka, E. \& Omokolo, N.D. (2018). Guaiacol Peroxidase heritability in tolerance of cocoa (Theobroma cacao L.) to Phytophthora megakarya, agent of cocoa black pod disease. International Journal of Agricultural Policy and Research, 6(2), 7-20.

Sogn, T.A., Dragicevic, I., Linjordet, R., Krogstad, T., Eijsink, V.G.H. \& Eich-Greatorex, S. (2018). Recycling of biogas digestates in plant production: NPK fertilizer value and risk of leaching. International Journal of Recycling of Organic Waste in Agriculture, 7, 49-58. https://doi.org/10.1007/ s40093-017-0188-0

Stirling, G.R., Halpin, N.V. \& Bell, M.J. (2011). A surface mulch of crop residues enhances suppressiveness to plant-parasitic nematodes in sugarcane soils. Nematropica, 41, 107-119.

Summers, H. (2011). Effects of organic manure on nematode control. Journal of Diseases and Pests Control in Tropics, 7, 190-191.

Sun, D., Hale, L., Kar, G., Soolanayakanahally, R. \& Adl, S. (2018). Phosphorus recovery and reuse by pyrolysis: applications for agriculture and environment. Chemosphere, 194, 682-691. https://doi.org/10.1016/j.chemosphere.2017.12.035

Thoden, T. C., Korthals, G. W. \& Termorshuizen, A. J. (2011). Organic amendments and their influences on plant-parasitic and free-living nematodes: A promising method for nematode management. Nematology, 13, 133-153. https:// doi.org/10.1163/138855410X541834

Tian, W., Wang, L., Li, Y., Zhuang, K., Li, G., Zhang, J., Xingji Xiao, X. \& Xi, Y. (2015). Responses of microbial activity, abundance, and community in wheat soil after three years of heavy fertilization with manure-based compost and inorganic nitrogen. Agriculture, Ecosystems and Environment, 213, 219-227. https://doi.org/10.1016/j.agee.2015.08.009

Tiyagi, S.A., Safiuddin, Rizvi, R., Mahmood, I. \& Khan, Z. (2015). Evaluation of organic matter, bio-inoculants and inorganic fertilizers on growth and yield attributes of tomato with respect to the management of plant-parasitic nematodes. Emirates Journal of Food and Agriculture, 27(8), 602-609. https://doi.org/10.9755/ejfa.2015.04.036

UNL (2019). Interactive Diagnostic Key to Plant Parasitic, Free living and Predaceous Nematodes. University of Nebraska- 
Lincoln Nematology Lab. (Accessed 15 January 2019). Retrieved from https://nematode.unl.edu/key/nemakey.htm

Wang, K. H., McSorley, R. \& Gullaher, R. N. (2004). Nematode community changes associated with decomposition of Crotalaria juncea amendment in litter gags. Applied Soil Ecology, 27, 31- 45. https://doi.org/10.1016/j.apsoil.2004.03.006

Wei, M., Hu, G., Wang, H., Bai, E., Lou, Y., Zhang, A. \& Zhuge, Y. (2017). 35 years of manure and chemical fertilizer application alters soil microbial community composition in a Fluvo-aquic soil in Northern China. European Journal of Soil Biology, 82, 27-34. https://doi.org/10.1016/j.ejsobi.2017.08.002

Xie, H., Li, J., Zhu, P., Peng, C., Wang, J., He, H. \& Zhang, X. (2014). Long-term manure amendments enhance neutral sugar accumulation in bulk soil and particulate organic matter in a Mollisol. Soil Biology and Biochemistry, 78, 4553. https://doi.org/10.1016/j.soilbio.2014.07.009

Yan, X., Wang, D.J., Zhang, H.L., Zhang, G. \& Wei, Z.Q. (2013). Organic amendments affect phosphorus sorption characteristics in a paddy soil. Agriculture, Ecosystems and Environment, 175, 47-53. https://doi.org/10.1016/j. agee.2013.05.009
Yanelis, A., Hernández-Rodríguez, A., Heydrich-Pérez, M., El Jaziri, M. \& Hernández-Lauzardo, A.N. (2012). Management of black pod rot in cacao (Theobroma cacao L.). Fruits, 67, 41-48. https://doi.org/10.1051/fruits/2011065

Yu, H.Y., Ding, W.X., Luo, J.F., Donnison, A. \& Zhang, J.B. (2012). Long-term effect of compost and inorganic fertilizer on activities of carbon-cycle enzymes in aggregates of an intensively cultivated sandy loam. Soil Use and Management, 28, 347-360. https://doi.org/10.1111/j.14752743.2012.00415.x

Zhang, M.H., Cederwall, R.T., Yio, J.J., Xie, S.C. \& Lin, J.L. (2001). Objective analysis of ARM IOP Data, Method and Sensitivity. Lawrence Livermore National Laboratory, Livermore California. 311 pp. https://doi.org/10.1175/15200493(2001)129<0295:OAOAID>2.0.CO;2

Zhang, X., Dong, W., Dai, X., Schaeffer, S., Yang, F., Radosevichb, M., Xu, L., Liu, X. \& Sun, X. (2015). Responses of absolute and specific soil enzyme activities to long term additions of organic and mineral fertilizer. Science of the Total Environment, 536, 59-67. https://doi.org/10.1016/j. scitotenv.2015.07.043 